\title{
Interaction of Whey Lactoferrin with Copper Immobilized in Polyacrylamide Cryogel
}

\author{
Carvalho BMA ${ }^{1 *}$, Carvalho LM², Silva Jr WF', Minim LA ${ }^{3}$ and Carvalho GGP4
}

${ }^{1}$ Department of Chemistry, Biotechnology and Bioprocess Engineering, Federal University of São João Del Rei, Ouro Branco, MG 36420-000, Brazil

${ }^{2}$ Department of Veterinary, Federal University of Viçosa, Viçosa, MG 36570-000, Brazil

${ }^{3}$ Department of Food Technology, Federal University of Viçosa, Viçosa, MG 36570-000, Brazil

${ }^{4}$ Department of Animal Science, Federal University of Bahia, Salvador, BA 40110-909, Brazil

\begin{abstract}
Design and optimization of Immobilized Metal Affinity Chromatography (IMAC) processes require deep knowledge of driving factors responsible for interaction between immobilized metal and biomolecules. Based on this requirement, interactions between lactoferrin from cheese whey and IDA-C $\mathrm{Cu}^{2+}$-cryogel system was investigated. Data from adsorption of lactoferrin in the system at $\mathrm{pH} 6,7$ and 8 , as well as $\mathrm{NaCl}$ concentration from 200 to $1000 \mathrm{mmol} \mathrm{L}^{-1}$ were adjusted Langmuir, Freundlich, Temkin and Langmuir-Freundlich isotherm models. Although all models were able to explain the interaction lactoferrin-cryogel system, the Langmuir-Freundlich model was the most accurate one. In addition, it could explain quantitatively the cooperativity and heterogeneity of the bounds between protein and matrix. The methods used in this project are useful for both better understanding of the protein-immobilized metal interactions and developing preparative scale IMAC.
\end{abstract}

Keywords: IMAC; Adsorption of protein; Interactions; Separation

\section{Introduction}

Lactoferrin (LF) from cheese whey is a glycoprotein from the transferrin family, whose molecular mass is around $80 \mathrm{kDa}$. It has an iron atom in its inner and amino acid residues along its surface, such as histidine and tryptophan [1]. Given its wide application in medicine, biology, pharmaceutical and food industry, due to their biological properties, such as antiviral, antibacterial, antioxidant and immunomodulatory activities, several technologies of processing have been studied and developed for isolation of LF at high levels of purity. The majority of these processes are focused on chromatographic techniques, such as purification of lactoferrin by cation exchange [2], heparin-Sepharose affinity [3], ligand affinity [4] and heparinpoly(glycidyl methacrylate) affinity chromatography [5]. Because of the difficulties found in these biotechnological processes, such as the use of special columns and pieces of equipment, and the processing of complex solutions like cheese whey (whose particulates can reduce the resin porosity, leading to blockage of the column), the development of new techniques to separate and purify whey lactoferrin is necessary.

Cryogels are polymeric gels formed in moderately frozen conditions. They have large pores, which allow solutions containing cell fragments and particulates to be drained throughout chromatographic columns without causing their obstruction [1].

Immobilized Metal Affinity Chromatography (IMAC) is based on the differential affinity for chemical groups at the surface of some molecules shown by metals immobilized in solid matrix [6]. Such affinity arises from reversible coordination ligations between metal ion and amino acid residues (in the case of peptides), such as imidazole group in histidine, thiol in cysteine and indol in tryptophan, which donate electrons to the immobilized metal. In addition to the coordination binding, other driving forces, such as electrostatic, hydrophobic and Van der Waals, may be involved in the adsorption of protein in IMAC and it may not always be possible to determine their relative contributions $[7,8]$

Mathematical modeling is an essential part of the chromatographic theory for describing its dynamical process. It provides a procedure for predicting the dynamical behavior of solute in the column without extensive experiments. Due to different considerations of simplifications, several types of models have been established and applied to illustrate the behavior of chromatographic columns [9].

Then, the use of supermacroporous matrixes (e.g. cryogels), along with IMAC seems to be a promising alternative for capture of lactoferrin. Thus, the absorption of lactoferrin in cryogel supermacroporous matrix with immobilized $\mathrm{Cu}^{2+}$ at $30^{\circ} \mathrm{C}$, different $\mathrm{NaCl}$ concentrations (200, 600, 800 and $\left.1000 \mathrm{mmol} \mathrm{L}^{-1}\right)$ and $\mathrm{pHs}(6.0,7.0$ and 8.0) was analyzed in this work.

\section{Material and Methods}

\section{Synthesis of IDA-Cu${ }^{2+}$-cryogel resin}

Both the synthesis and the characterization of IDA- $\mathrm{Cu}^{2+}$-cryogel resins were performed in accordance with [10] works [11]. Cryocopolymerization reaction of solution containing acrylamide (AAm), N,N'-methylenebisacrylamide (MBAAm), Allyl Glycidyl Ether (AGE), $\mathrm{N}, \mathrm{N}, \mathrm{N}, \mathrm{N}^{\prime}$-tetramethylethylenediamine (TEMED) and ammonium persulfate (APS) was performed. Iminodiacetic acid (IDA) was used to immobilize copper in the matrix.

\section{Batch adsorption of lactoferrin and obtainment of equilibrium data}

Static method was used to obtain absorption at each condition

*Corresponding author: Carvalho BMA, Department of Chemistry, Biotechnology and Bioprocess Engineering, Federal University of São João Del Rei, Ouro Branco, MG 36420-000, Brazil, Tel: +55-021- 31-374-139-62; E-mail: brunamara.carvalho@gmail.com

Received October 31, 2014; Accepted November 27, 2014; Published December 01, 2014

Citation: Carvalho BMA, Carvalho LM, Silva Jr WF, Minim LA, Carvalho GGP (2014) Interaction of Whey Lactoferrin with Copper Immobilized in Polyacrylamide Cryogel. J Bioprocess Biotech 4: 189 doi: 10.4172/21559821.1000189

Copyright: ( 2014 Carvalho BMA, et al. This is an open-access article distributed under the terms of the Creative Commons Attribution License, which permits unrestricted use, distribution, and reproduction in any medium, provided the original author and source are credited. 
analyzed. Approximately $30 \mathrm{mg}$ of cryogel matrix were weighed in eppendorf tubes and equilibrated with $400 \mu \mathrm{L}$ of equilibration buffer $(20$ mmol L ${ }^{-1} \mathrm{HEPES}, 0.2 \mathrm{~mol} \mathrm{~L}^{-1} \mathrm{NaCl}$, $\mathrm{pH}$ 7.0) for $2 \mathrm{~h}$ under mild stirring. After that, different volumes $(0-300 \mu \mathrm{L})$ of $10 \mathrm{mg} \mathrm{mL}^{-1}$ lactoferrin solution were added to the tubes along with equilibration buffer enough to make the volume up to $1200 \mu \mathrm{L}$, leading to final concentrations of $0,0.1,0.2,0.3,0.4,0.6,0.9,1.2,1.5,1.8$ and $2.2 \mathrm{mg} \mathrm{mL}^{-1}$ lactoferrin. The tubes were kept under constant agitation for $24 \mathrm{~h}$ in a temperature controlled biological incubator (101 M Mod BOD/3 Eletrolab' Brazil) at $30^{\circ} \mathrm{C}$ up to establish the equilibrium. Then, the resins were taken away from tubes and the concentration of lactoferrin in the supernatant was measured according to the Bradford method [12] at $495 \mathrm{~nm}$ (Thermo Scientific Model BIOMATE 3) using calibration curve.

The amount of protein retained in the resin was obtained by mass balance (Equation 1).

$$
q=\frac{V}{m}\left(C_{o}-C_{b}\right)
$$

where $\mathrm{q}\left(\mathrm{mg} \mathrm{g}^{-1}\right)$ is the concentration of protein in the resin, $\mathrm{V}(\mathrm{mL})$ is the volume of the liquid phase, $\mathrm{M}(\mathrm{g})$ is the mass of the solid phase, $\mathrm{C}_{0}$ $\left(\mathrm{mg} \mathrm{mL}^{-1}\right)$ is the initial lactoferrin concentration in the liquid phase and $\mathrm{C}\left(\mathrm{mg} \mathrm{mL}^{-1}\right)$ is the final lactoferrin concentration in the supernatant after equilibrium was reached. The experiment was conducted using a fractional factorial design with three concentrations of salt $(200 \mathrm{mmol}$ $\mathrm{L}^{-1}, 600 \mathrm{mmol} \mathrm{L}^{-1}$ and $\left.1000 \mathrm{mmol} \mathrm{L}^{-1}\right)$ and three $\mathrm{pHs}(6.0,7.0$ and 8.0).

\section{Modeling of equilibrium data}

Several researchers have shown that the relationship between free proteins in a solution and those absorbed in a matrix (at the equilibrium) may be described by the [13] isotherm. Chase [14] wrote a mass transfer equation which is coherent to the Langmuir isotherm. Protein mass transfer from solution to the matrix can be described by:

$$
\frac{d q}{d t}=k_{1} C\left(q_{m(L)}-q\right)-k_{2} q
$$

Where $\mathrm{C}$ is the concentration of protein in the liquid phase, $\mathrm{q}$ is the concentration of adsorbed protein, $\mathrm{q}_{\mathrm{m}}$ is the resin maximum binding capacity and $\mathrm{t}$ is time. $\mathrm{k}_{1}$ and $\mathrm{k}_{2}$ are parameters which represent the rates of adsorption and desorption of protein to and from the immobilized metal ions. Supposing that all biding sites have same potential energy, regardless of their source, and that protein-biding site interactions are of type 1:1 (i.e. one molecule of protein is bound to one biding site), during the equilibrium, equation 2 can be reduced to:

$$
q=\frac{q_{m(L)} C^{*}}{\left(k_{d}+C^{*}\right)}
$$

Where $\mathrm{q}_{\mathrm{m}}$ is the resin maximum binding capacity, $\mathrm{k}_{\mathrm{d}}$ is a dissociation constant, $\mathrm{q}$ and $\mathrm{C}$ are protein concentration in the matrix and supernatant, respectively.

To validate the supposition of having the biding sites at the matrix surface, many linear transformations of equation 3 were performed, including the double and semi-reciprocal plots [15], as well as the Scatchard [16] plot:

Double reciprocal:

$$
\frac{1}{q^{*}}=\frac{1}{q_{m(L)}}+\frac{K_{d}}{q_{m(L)}} \cdot \frac{1}{C}
$$

Semi-reciprocal

$$
\frac{C^{*}}{q^{*}}=\frac{K_{d}}{q_{m(L)}}+\frac{C^{*}}{q_{m(L)}}
$$

Scatchard

$$
\frac{q^{*}}{C^{*}}=\frac{q_{m(L)}}{K_{d}}-\frac{q^{*}}{K_{d}}
$$

The shape of $\mathrm{q}^{*} / \mathrm{C}^{*}$ vs $\mathrm{q}^{*}$ plots are particulary sensitive during independent, dependent non-identical or cooperative interaction process between protein and immobilized metal ion. If $\mathrm{q}^{*} / \mathrm{C}^{*}$ vs $\mathrm{q}^{*}$ is convex, negative cooperation is observed. If its plot is linear, interactions between protein and ligand are independent. On the other hand, if $\mathrm{q}^{*} / \mathrm{C}^{*}$ vs $\mathrm{q}^{*}$ plot is concave, there is positive cooperation in the adsorption process.

As protein-ligand interactions are frequently characterized by the participation of dependent binding sites, the Langmuir isotherm cannot describe experimental data satisfactorily. Another well-known isotherm, which is usually used to describe adsorption behavior, is the Freundlich [17] one. It correlates the concentration of adsorbed protein to the solute concentration:

$$
q^{*}=K C^{\eta}
$$

Where $\mathrm{K}$ and $\eta$ are the equilibrium constant and capacity factor of Freundlich isotherm, respectively. $\mathrm{K}$ and $\eta$ are constants for a particular protein-immobilized metal [17]. Although it is usually applied in a strictly empiric way, this equation may have interesting theoretical application in terms of adsorption on energetically heterogenic surface. One of the Freundlich isotherm limitations is that, according to it, amount of adsorbed protein increases indefinitely with concentration of protein in solution.

Reversible adsorption of proteins can also be described by Temkin's isotherm model, which was originally developed for adsorption of gases in heterogeneous surfaces. This model assumes an adsorption characterized by uniform distribution of ligation energy as result of the equation that predicts its [18]:

$$
q^{*}=q_{T} \ln \left(1+K_{T} C^{*}\right)
$$

Where $\mathrm{K}_{\mathrm{T}}\left(\mathrm{mol} \mathrm{L}^{-1}\right)$ is the equilibrium constant of ligation, which corresponds to the maximum ligation energy $\left(\mathrm{K}_{\mathrm{T}}=\mathrm{e}^{-(\Delta \mathrm{Gmax} / \mathrm{RT})}\right), \mathrm{C}^{*}(\mathrm{~mol}$ $\left.\mathrm{L}^{-1}\right)$ is the concentration of protein in solution at the equilibrium and $\mathrm{q}_{\mathrm{T}}$ is the surface differential adsorption capacity (in relation to the protein) per unity of energy.

The Temkin's isotherm has two main advantages on clarifying the heterogeneous nature of protein adsorption to ion exchanger and affinity resins when it is compared to the other ones (e.g. Freundlich and Langmuir) [19,20]: 1) it is described by two physically relevant parameters, whose values can be determined through adsorption equilibrium experiments; 2) it matches to Henry's law, which is an item necessary to explain the theory of local equilibrium in adsorption equilibrium for predictive chromatography.

In addition to Temkin's isotherm, Langmuir and Freundlich models were combined in order to overcome their inadequacies (e.g. indefinite increase of amount of adsorbed protein with concentration of protein in solution), leading to the Langmuir-Freundlich [21] model (Equation 9). This isotherm has been mentioned as an adequate way to describe the behavior of proteins in affinity resins.

$$
q^{*}=\frac{q_{m(L F)}\left(C^{*}\right)^{\eta}}{K_{d}^{*}+\left(C^{*}\right)^{\eta}}
$$




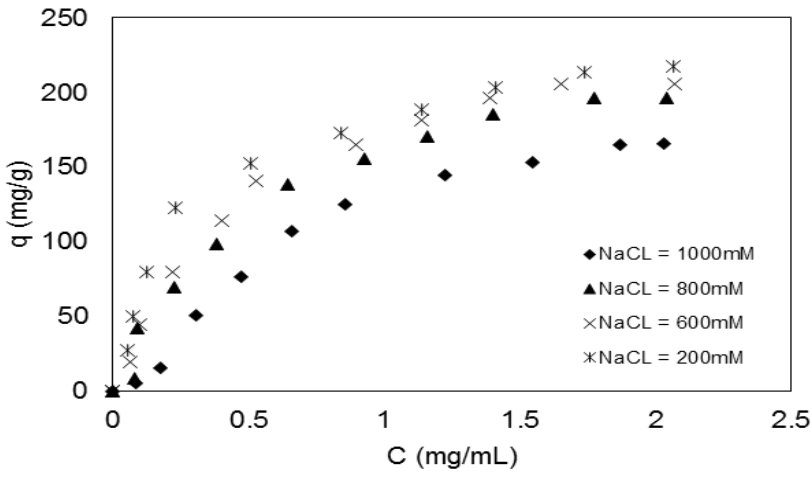

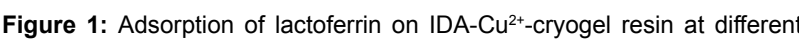
ionic strengths (HEPES buffer, $200-1000 \mathrm{mmol} \mathrm{L}^{-1} \mathrm{NaCl}$; $\mathrm{pH} 8.0,30^{\circ} \mathrm{C}$ ).

Where $\mathrm{K}_{\mathrm{d}}^{*}$ is the constant of apparent dissociation, $\mathrm{q}_{\mathrm{m}}$ is the maximum capacity of ligation and $\eta$ is the Langmuir-Freundlich numeric coefficient. By analogy to multiple interactions made by proteins with ligands, it can be suggested that equation 9 can be used as model for cooperative adsorption. As this equation has three terms whose values must be found, it is better to explain adsorptions of heterogeneous nature and the adsorption cooperativity. For purely independent reasons, non-interative sites have $\eta=1$. When $\eta>1$, positive cooperation is suggested, while $0<\eta<1$ indicates negative cooperation in the binding process. Thus, value of $\eta$ can be used as an empiric coefficient that represents what kind of cooperativity extension is present in the studied interaction.

\section{Results and Discussions}

\section{Ionic strength effect}

Figure 1 shows adsorption isotherms for lactoferrin- IDA-Cu ${ }^{2+}-$ criogel system. It can be observed that protein adsorption decreases with ionic strength increase. Similar behavior was obtained by [22] and [23] in adsorption of lysozyme on cooper ions immobilized in. Graham and co-authors [24], when the adsorption of lysozyme on CL-4B Sepharose with immobilized $\mathrm{Cu}^{2+}$ was analyzed, found diverse adsorption behaviors depending on the solution's $\mathrm{pH}$ and ion strength. In this matrix, the adsorption was positively influenced by ionic strength increase through all $\mathrm{pH}$ analyzed in their work. The TACN gel adsorption capacity was directly infuenced by $\mathrm{pH}$ and ionic strength, wherein at low values of $\mathrm{pH}$ (e.g. 5), the enzyme adsorption rised with $\mathrm{NaCl}$ concentration increase. However, at higher $\mathrm{pH}$ values (e.g. 9), adsorption behavior was reversed, wherein the maximum adsorption capacity was found in solutions without salt, which reinforces the complexity of phenomena behind IMAC and that the differential affinity of metal ions to biomolecules in solution is dependent on not only the chelate ion but also the composition of the mobile phase.

It is believed that protein adsorption in IMAC is result of cumulative effects of electrostatic, hydrophobic and/or coordination interactions. Though the addition of salt reduces electrostatic interactions, it also strengthens coordination and hydrophobic [6]. As consequence, different adsorption tendencies can be obtained for different proteins according to their hydrophobia. In this study, the increase of lactoferrin adsorption throughout ionic strength reduction indicates high effect of electrostatic interactions on the process. The resin adsorption capacities were significantly higher at $200 \mathrm{mmol} \mathrm{L}^{-1} \mathrm{NaCl}$; thus, it seems to be the best condition to achieve high protein biding capacity.
The higher adsorption capacity at low $\mathrm{NaCl}$ concentration may be due to non-specific interactions between protein and matrix produced by hydrophobic amino acid residues, such as cysteine and tryptophan. At $\mathrm{pH} 8$, histidine is uncharged $\left(\mathrm{pK}_{\mathrm{a}}=6.0\right)$, which would provide additional hydrophobic force to the interaction -instead of electrostatic repulsion as if $\mathrm{pH}$ was lower than 6.0)-, besides more available electrons pairs to be donated to cooper ions. These amino acids are also considered to be responsible for affinity phenomenon in IMAC.

Data of lactoferrin adsorption on IDA-Cu ${ }^{2+}$ - cryogel at conditions discussed above were also adjusted to four isotherm models, that is; Langmuir, Freundlich, Temkin and Langmuir-Freundlich (Figure 2a2d).

The Langmuir's model has been used to analyze adsorption data of protein on affinity resins $[23,25]$. In this study, Langmuir's model showed excellent accuracy, mainly at low salt concentrations. Its inability to describe experimental data was more visible at higher ionic strengths, though its coefficients of determination continued satisfactorily high. Estimated parameters from Langmuir, Freundlich, Temkin isotherms are shown in Table 1.

Although Freundlich's isotherm was adequate to explain experimental data, it was not fully explored in this work. Low binding capacity and high binding affinity are indicatives of larger deviations Temkin's isotherm (Table 1). Then, this model was not able to explain the behavior of protein adsorption. However, it has been successfully used to explain equilibrium data from heterogeneous protein adsorption in works where cooper was used as chelating metal $[19,20]$.

Langmuir-Freundlich model [26] was the most appropriated one to describe experimental data at all analyzed conditions, yielding excellent coefficients of determination $\left(\mathrm{R}^{2}>0.99\right)$ (Figure 2a-2e). Besides, it could explain even the sigmoid ( $\mathrm{S}$ ) variation in the Langmuir's isotherm, observed at high salt concentrations. This change on isotherms shape with increase of ionic strength is an indicator of variation on relative contribution of electrostatic, hydrophobic and/or coordination interactions, as well as of change in the adsorption mechanism.

Values of $\eta>1$ in all studied conditions, except for $200 \mathrm{mmol}$ $\mathrm{L}^{-1}$, indicate positive cooperation and adsorption of heterogeneous nature. This model is appropriate to explain the mechanism of protein adsorption at high salt concentration, in a quantitative way, in terms of $\eta$. Values of $\eta$ increase with ionic strength rising, suggesting cooperation effect raise on protein-matrix binding. In despite of these facts, maximum adsorption values were obtained at $600 \mathrm{mmol} \mathrm{L}^{-1} \mathrm{NaCl}$.

Nevertheless, experimental values of maximum protein adsorption $\left(\mathrm{q}_{\mathrm{m}}\right)$ are much lower than the estimated (theoretical) ones, since they are based on 1:1 protein-ligand stoichiometry. As it is known, one protein molecule can interact with more than one metal ion, leading to lower actual $\mathrm{q}_{\mathrm{m}}$. It is also related to protein's tridimensional shape, and because its shape depends on the solution conditions (salt concentration, $\mathrm{pH}$ and temperature), the degree of heterogeneity of protein adsorption changes also varies due to these conditions.

Figure 3 shows the Scatchard's non-linear $\left(\mathrm{q}^{*} / \mathrm{C}^{*}\right.$ vs $\left.\mathrm{q}^{*}\right)$ for experimental data. These plots' shape is particularly sensitive to presence of independent interactions, as well as to coordination bindings. Scatchard plot provides information about cooperation effects; its different maximum values through the studied $\mathrm{NaCl}$ concentrations imply change on adsorption mechanism through those conditions, reinforcing the cooperation effect on this process. Then, the hypotheses (i) all biding sites have same potential energy, (ii) interactions between protein and ligand are of type 1:1 stoichiometry, (iii) and binding sites 


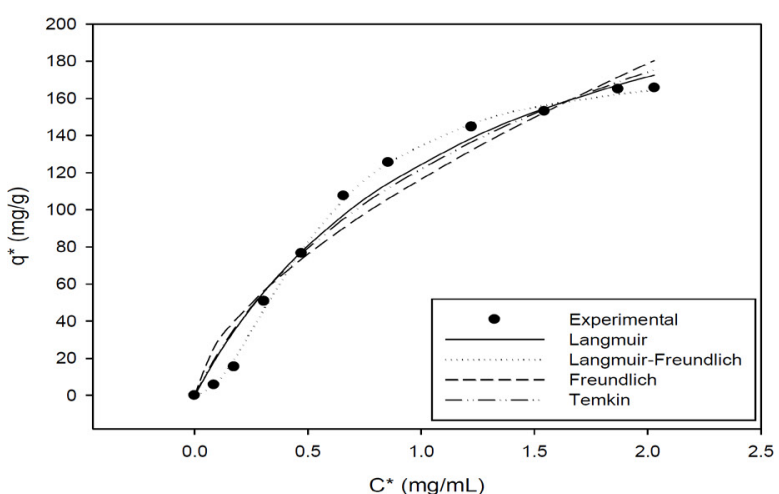

(a)

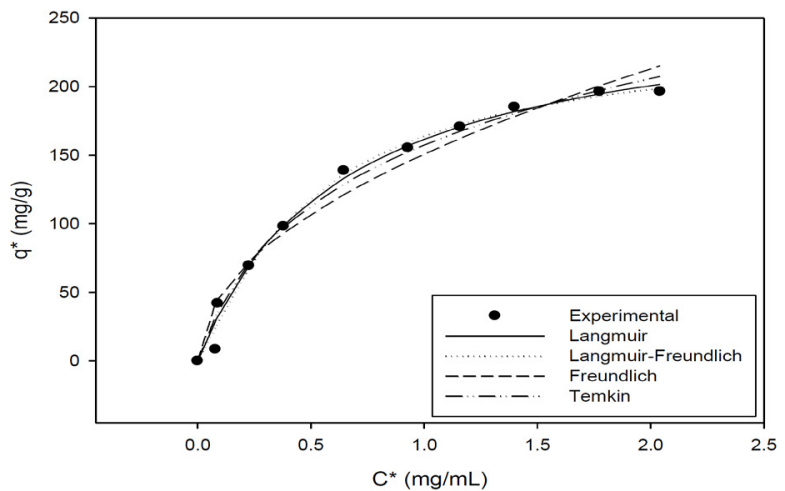

(c)

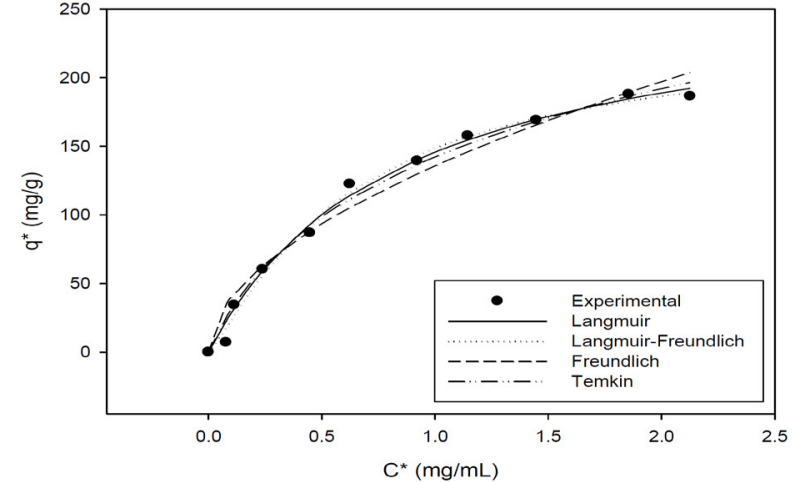

(b)

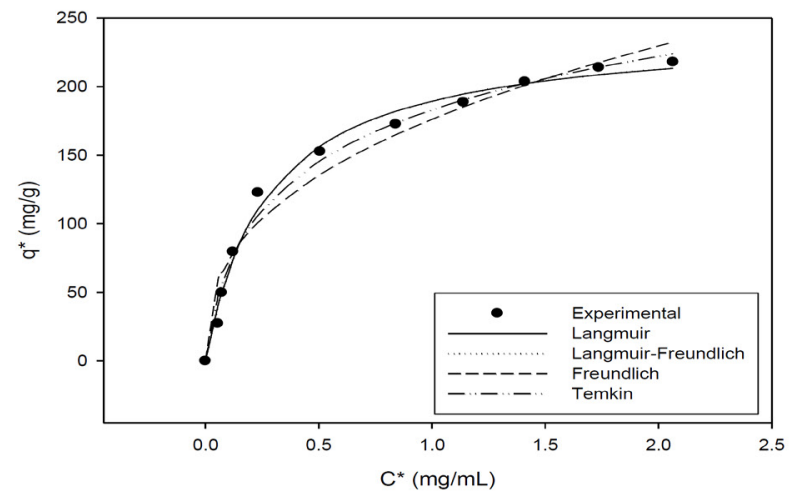

(d)

Figure 2: Comparison of accuracy of the Langmuir, Freundlich, Temkin and Langmuir-Freundlich isotherm models to predict lactoferrin adsorption IDA-Cu²+ cryogel at different ionic strengths (temperature was $30^{\circ} \mathrm{C}$ and $\mathrm{pH}=8.0$ ); (a) $1000 \mathrm{mmol} \mathrm{L}^{-1}$, (b) $800 \mathrm{mmol} \mathrm{L}^{-1}$, (c) $600 \mathrm{mmol} \mathrm{L}^{-1}$, (d) $200 \mathrm{mmol} \mathrm{L}^{-1} \mathrm{NaCl}$.

\begin{tabular}{|c|c|c|c|c|}
\hline \multirow{2}{*}{ Theoretical Model } & \multicolumn{4}{|c|}{$\mathrm{NaCl}$ concentration (mmol L-1) } \\
\hline & 200 & 600 & 800 & 1000 \\
\hline \multicolumn{5}{|l|}{ Langmuir } \\
\hline$K_{d}(\mu \mathrm{mol} \mathrm{L}-1)$ & 0.2751 & 0.6374 & 0.8472 & 1.1984 \\
\hline$q_{\mathrm{m}}(\mathrm{mg} / \mathrm{mg}$ gel $)$ & 274.40 & 264.55 & 263.59 & 241.61 \\
\hline \multicolumn{5}{|l|}{ Freundlich } \\
\hline$K\left(10^{-3} \mathrm{~L} / \mathrm{mg}\right.$ gel $)$ & 176.2 & 150.7 & 135.7 & 116.7 \\
\hline$\eta$ & 2.6207 & 2.0082 & 1.8562 & 1.6259 \\
\hline \multicolumn{5}{|l|}{ Temkin } \\
\hline$K_{T}\left(\mathrm{~L} \mathrm{~mol}^{-1}\right)$ & 22.5191 & 6.6284 & 4.5021 & 2.594 \\
\hline$q_{T}(\mathrm{mg} / \mathrm{mg} \mathrm{gel})$ & 57.9874 & 77.4595 & 83.3876 & 95.5819 \\
\hline \multicolumn{5}{|l|}{ Langmuir-Freundlich } \\
\hline$K_{d}^{*}(\mu \mathrm{M})$ & 0.318 & 0.4502 & 0.3872 & 0.2785 \\
\hline$q_{m}(\mathrm{mg} / \mathrm{g}$ gel $)$ & 242.2 & 244.7 & 237.8 & 178.5 \\
\hline$\eta$ & 1.85 & 1.16 & 1.12 & 0.99 \\
\hline
\end{tabular}

a Buffer composition: HEPES $20 \mathrm{mmol} \mathrm{L}^{-1} ; 200-1000 \mathrm{mmol} \mathrm{L}^{-1} \mathrm{NaCl} ; \mathrm{pH} 8.0 ; 30^{\circ} \mathrm{C}$.

Table 1: Estimated parameters of isotherm models for adsorption of whey lactoferrin on IDA-Cu ${ }^{2+}$ - cryogel system at different ionic strength conditions ${ }^{\mathrm{a}}$.

have independent nature, are no longer valid, invalidating the Langmuir model at these conditions.

Jiang and Hearn [27] observed significant changes in Scatchard's plots shapes with increase of salt concentration for adsorption of glair lysozyme on IDA-Cu ${ }^{2+}$-resin. However, according to these authors, the intensity of deviation between these plots depends on the effective protein concentration at the immobilized ligand micro-environment.

\section{pH effect}

The influence of $\mathrm{pH}$ on the direction of lactoferrin adsorption on IDA- $\mathrm{Cu}^{2+}$-cryogel (Figure 4) was investigated in the rage of 6 to 8 , at $30^{\circ} \mathrm{C}$ and $200 \mathrm{mmol} \mathrm{L}^{-1} \mathrm{NaCl}$. It was observed that the larger the $\mathrm{pH}$, the higher the adsorption capacity for this system. Similar results were noticed when obtaining lysozyme and nuclease adsorption isotherms from interaction CS-IDA- $\mathrm{Cu}^{2+}$ [22]. Indeed, optimum $\mathrm{pH}$ for this process depends on the used chelating chemical, the nature of the metal ion and the protein tridimensional shape.

Protons affect the net charge of both immobilized ion and protein. The $\mathrm{pH}$ range used in IMAC is usually 5-8 for immobilized ions, such as $\mathrm{Cu}^{2+}, \mathrm{Ni}^{2+}, \mathrm{Co}^{2+}$ e $\mathrm{Zn}^{2+}$, where they coordinate mainly to hystidin residues at protein surface $[6,28]$. However, for metal ions, such as $\mathrm{Ca}^{2+}$ and $\mathrm{Fe}^{3+}$, maximum adsorption occurs at low pHs (e.g. 5-6) $[29,30]$. Sulkowski [28] observed the rentention of Bovine Serum Albumin (BSA) in IDA- $\mathrm{Ni}^{2+}$-sepharose was higher at $\mathrm{pH} 7.0$ and negligible at $\mathrm{pH}$ 6.0 (Table 2).

Figure 5 shows Langmuir, Freundlich, Temkin and LangmuirFreundlich isotherms. Though their coefficient of determination were relatively high, the three first models were not able to explain satisfactorily the adsorption of lactoferrin on IDA- $\mathrm{Cu}^{2+}$-cryogel, which is seen by the deviations of simulated adsorption values from experimental data. Langmuir-Freundlich model yielded the best estimations at all investigated $\mathrm{pH}$ values (Figure 5a-5c). Langmuir-Freundlich model parameters (Table 2) indicate that maximum adsorption capacity, 
Citation: Carvalho BMA, Carvalho LM, Silva Jr WF, Minim LA, Carvalho GGP (2014) Interaction of Whey Lactoferrin with Copper Immobilized in Polyacrylamide Cryogel. J Bioprocess Biotech 4: 189 doi: 10.4172/2155-9821.1000189

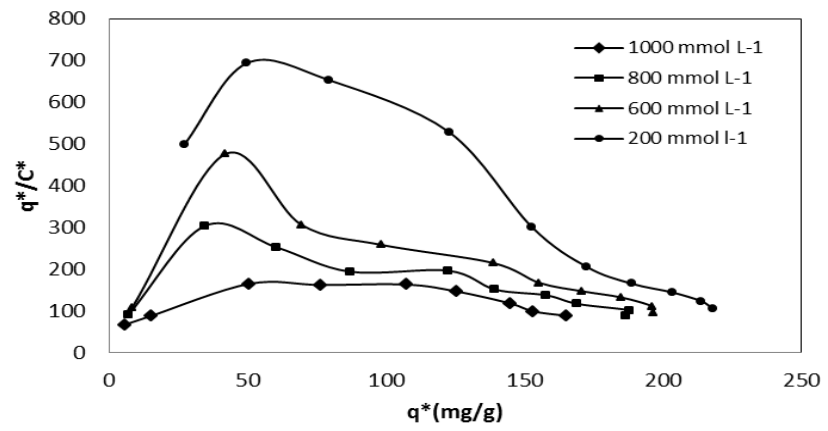

Figure 3: Scatchard's analysis for adsorption of lactoferrin on IDA-Cu+2+-cryogel in $20 \mathrm{mmol} \mathrm{L}^{-1} \mathrm{HEPES}$ buffer, $200-1000 \mathrm{mmol} \mathrm{L-1} \mathrm{NaCl}^{2} \mathrm{pH} 8.0,30^{\circ} \mathrm{C}$.

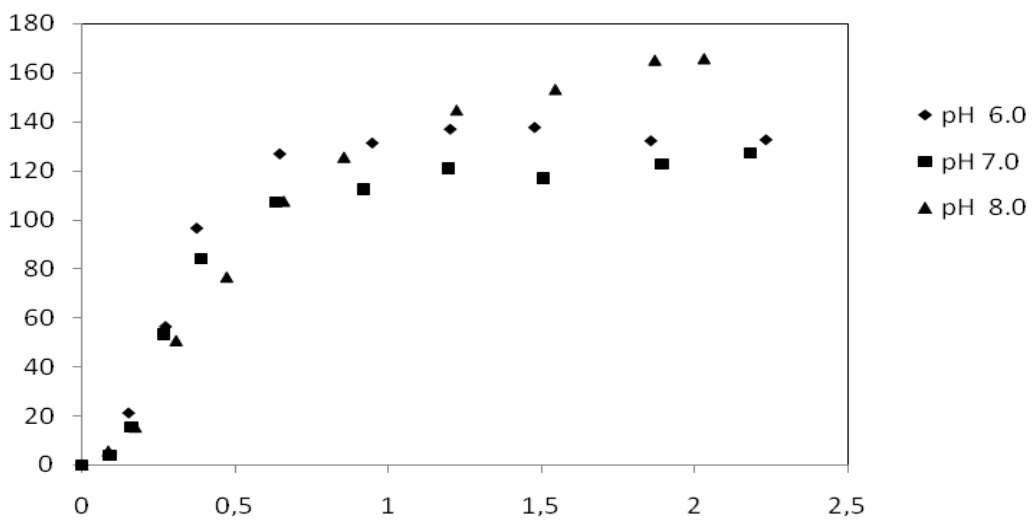

Figure 4: Adsorption of lactoferrin on IDA-Cu' ${ }^{2+}$-cryogel in HEPES buffer, $\mathrm{pH} 6.0-8.0,200 \mathrm{mmol} \mathrm{L}{ }^{-1} \mathrm{NaCl}$ and $30^{\circ} \mathrm{C}$ ).

\begin{tabular}{|c|c|c|c|}
\hline \multirow{2}{*}{ Theoretical Model } & \multicolumn{3}{|c|}{$\mathrm{pH}$} \\
\hline & 6.0 & 7.0 & 8.0 \\
\hline \multicolumn{4}{|l|}{ Langmuir } \\
\hline$K_{d}(\mu \mathrm{mol} \mathrm{L}-1)$ & 0.2071 & 0.5264 & 0.2751 \\
\hline$q_{m}(\mathrm{mg} / \mathrm{g}$ gel $)$ & 211.138 & 165.2006 & 274.4003 \\
\hline \multicolumn{4}{|l|}{ Freundlich } \\
\hline$K\left(10^{-3} \mathrm{~L} / \mathrm{g}\right.$ gel $)$ & 163.5 & 165.2 & 176.2 \\
\hline$\eta$ & 3.1062 & 2.4821 & 2.6207 \\
\hline \multicolumn{4}{|l|}{ Temkin } \\
\hline$K_{T}\left(\mathrm{~L} \mathrm{~mol}^{-1}\right)$ & 40.0969 & 15.6483 & 22.5191 \\
\hline$q_{T}(\mathrm{mg} / \mathrm{g}$ gel $)$ & 40.495 & 60.9088 & 57.9874 \\
\hline \multicolumn{4}{|l|}{ Langmuir-Freundlich } \\
\hline$K_{d}^{*}(\mu \mathrm{mol} \mathrm{L}-1)$ & 0.1552 & 0.0794 & 0.2785 \\
\hline$q_{m}(\mathrm{mg} / \mathrm{g}$ gel $)$ & 203.1 & 196.2 & 242.2 \\
\hline$\eta$ & 1.1192 & 1.7007 & 0.9955 \\
\hline
\end{tabular}

a $20 \mathrm{mmol} \mathrm{L}^{-1} \mathrm{HEPES}, \mathrm{pH} 6.0-8.0,200 \mathrm{mmol} \mathrm{L}^{-1} \mathrm{NaCl}, 30^{\circ} \mathrm{C}$.

Table 2: Parameters of adsorption equilibrium for whey lactoferrin on IDA-Cu${ }^{2+}-$ cryogel at different $\mathrm{pH}_{\text {values }}{ }^{\text {a }}$

$\mathrm{q}_{\mathrm{m}}$, was higher at $\mathrm{pH}$ 8. The elevation of this parameter may be due to the role of histidine $\left(\mathrm{pK}_{\mathrm{a}}=6\right)$ in protein- immobilized metal ion interactions. Studies performed by Andersson and Sulkowski [31] showed that residues of amino acids, such as lysine and arginine also significantly influence adsorption process at $\mathrm{pH}$ above 8 . At $\mathrm{pHs}$ equal to or lower than 7 , charged amino acids affect protein retention, mainly due to changes in driving forces between metal ion and amino acid residues [32]. At alkaline conditions, however, amino acid residues on the protein's surface will most likely be neutral or negatively charged, making them more bound to establish coordination bonds.
The binding affinity, that is, the inverse of the dissociation constant $\left(\mathrm{K}_{\mathrm{d}}^{*}\right)$, initially increases; then, it reaches a maximum value at $\mathrm{pH} 7$ and finally reduces. Similar tendencies were found for adsorption of ribonuclease $\mathrm{A}$ in $\mathrm{Cu}^{2+}$ - sepharose and for $\mathrm{BSA}$ in $\mathrm{Cu}^{2+}$ - superose at $\mathrm{pH}$ range of 5-7 [17,33]. Values of $\eta>1$ for all studied $\mathrm{pHs}$, except for $\mathrm{pH}$ 8 , suggest positive cooperation in the heterogeneous binding between lactoferrin and cryogel resin. Although $\eta$ values varied through the three pHs, these changes were not significant, which implies that the adsorption mechanism remained the same. 
Citation: Carvalho BMA, Carvalho LM, Silva Jr WF, Minim LA, Carvalho GGP (2014) Interaction of Whey Lactoferrin with Copper Immobilized in Polyacrylamide Cryogel. J Bioprocess Biotech 4: 189 doi: 10.4172/2155-9821.1000189

Page 6 of 7

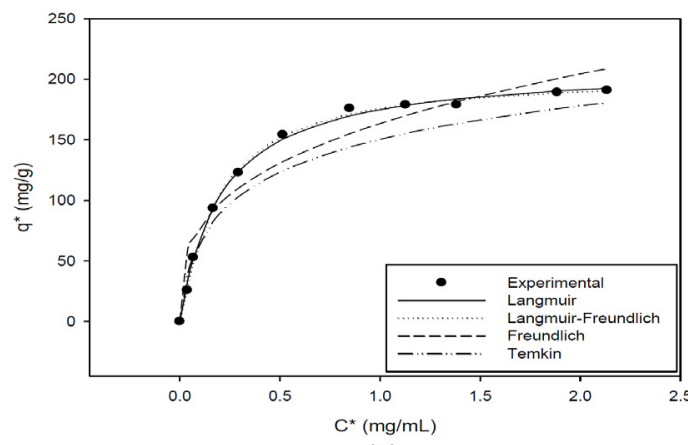

(a)

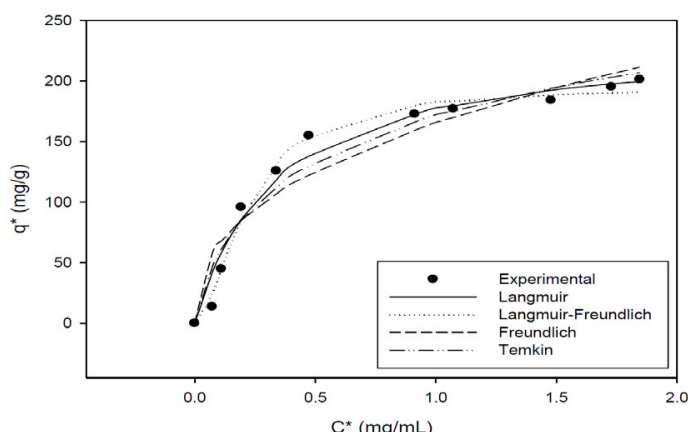

(b)

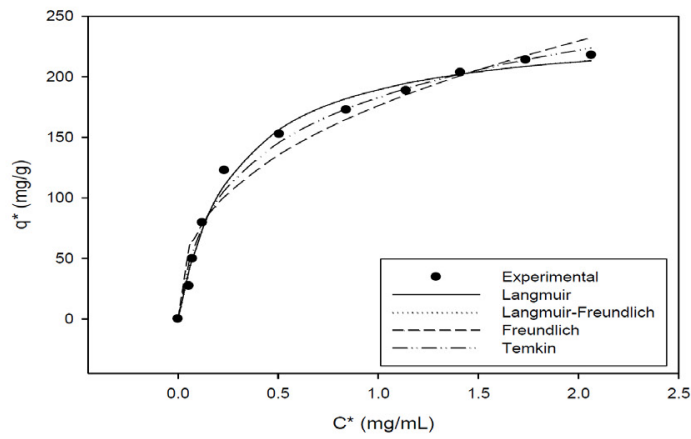

(c)

Figure 5: Comparison between several isotherm models for lactoferrin adsorption to IDA-Cu' ${ }^{2+}$ cryogel at three $\mathrm{pH}$ values: (a) 6.0 , (b) 7.0 e (c) 8.0 , temperature equal to $30^{\circ} \mathrm{C}$ and $200 \mathrm{mmol} \mathrm{L}^{-1} \mathrm{NaCl}$.

\section{Conclusion}

The results obtained from this work have important applications on immobilized metal affinity chromatography. Due to its high accuracy, Langmuir-Freundlich model parameters may be used to both describe interaction protein- immobilized ligand and simulate protein adsorption process at the conditions used to generate LangmuirFreundlich isotherm, which is valuable for designing separation processes by IMAC in preparative scale and forecasting its performance. Thus, these results also show benefic information to generate process for capturing of lactoferrin in large scales and consecutively, to meet processing demands for this high value molecule.

\section{References}

1. Carvalho BM, Da Silva LH, Carvalho LM, Soares AM, Minim LA, et al. (2013) Microcalorimetric study of the adsorption of lactoferrin in supermacroporous continuous cryogel with immobilized $\mathrm{Cu}(2+)$ ions. J Chromatogr A 1312: 1-9.

2. Hahn R, Schulz PM, Schaupp C, Jungbauer A (1998) Bovine whey fractionation based on cation-exchange chromatography. J Chromatogr A 795: 277-287.

3. Bläckberg L, Hernell O (1980) Isolation of lactoferrin from human whey by a single chromatographic step. FEBS Lett 109: 180-183.

4. Noppe W, Plieva FM, Galaev IY, Vanhoorelbeke K, Mattiasson B, et al. (2006) Immobilised peptide displaying phages as affinity ligands. Purification of lactoferrin from defatted milk. J Chromatogr A 1101: 79-85.

5. Chen L, Guo C, Guan Y, Liu H (2007) Isolation of lactoferrin from acid whey by magnetic affinity separation. Separation and Purification Technology 56:168174

6. Bresolin ITL, Everson AM,Bueno SMA (2009) Cromatografia de afinidadeporionsmetálicosimobilizados (IMAC) de biomoléculas: aspectosfundamentais e aplicações. Química Nova 32:1288-1296.
7. Ueda EK, Gout PW, Morganti L (2003) Current and prospective applications of metal ion-protein binding. J Chromatogr A 988: 1-23.

8. Sharma S, Agarwal GP (2002) Comparative studies on the metal sorption characteristics of chelating gels for immobilized metal ion affinity chromatography. Separation Science and Technology 37: 3491-3511.

9. Parveen S, Qamar S, Seidel-Morgenstern A (2015) Two-dimensional nonequilibrium model of liquid chromatography: Analytical solutions and moment analysis. Chemical Engineering Science 122: 64-77.

10. Arvidsson P, Plieva FM, Lozinsky VI, Galaev IY, Mattiasson B (2003) Direct chromatographic capture of enzyme from crude homogenate using immobilized metal affinity chromatography on a continuous supermacroporous adsorbent. J Chromatogr A 986: 275-290.

11. Carvalho BM, Carvalho LM, Silva WF Jr, Minim LA, Soares AM, et al. (2014) Direct capture of lactoferrin from cheese whey on supermacroporous column of polyacrylamide cryogel with copper ions. Food Chem 154: 308-314.

12. Bradford MM (1976) A rapid and sensitive method for the quantitation of microgram quantities of protein utilizing the principle of protein-dye binding Anal Biochem 72: 248-254.

13. Langmuir I (1916) The constitution and fundamental properties of solids and liquids. J Am Chem Soc 30:2263-2295.

14. Chase HA (1984) Prediction of the performance of preparative affinity chromatography. J Chromatogr 297: 179-202.

15. Hanes CS (1932) Studies on plant amylases: The effect of starch concentration upon the velocity of hydrolysis by the amylase of germinated barley.Biochem J 26: 1406-1421.

16. Scatchard G (1949) The Attraction of Proteins for Small Molecules and lons Ann NY Acad Sci 51: 660-672.

17. Hutchens TW, Yip TT (1990) Protein interactions with immobilized transition metal ions: quantitative evaluations of variations in affinity and binding capacity. Anal Biochem 191: 160-168. 
Citation: Carvalho BMA, Carvalho LM, Silva Jr WF, Minim LA, Carvalho GGP (2014) Interaction of Whey Lactoferrin with Copper Immobilized in Polyacrylamide Cryogel. J Bioprocess Biotech 4: 189 doi: 10.4172/2155-9821.1000189

18. Sips R (1950) Advances in Chemical Engineering. Chemical Engineering 18: 1024.

19. Johnson RD, Arnold FH (1995) Review: Multipoint binding and heterogeneity in immobilized metal affinity chromatography. Biotechnol Bioeng 48: 437-443.

20. Johnson RD, Arnold FH (1995) The Temkin isotherm describes heterogeneous protein adsorption. BiochimBiophys Acta 1247: 293-297.

21. Andrade JD (1985)Surface and Interfacial Aspects of Biomedical Polymers. Volume 2, Plenum, New York, USA.

22. Chen WY, Lee JF, Wu CF, Tsao HK (1997) Microcalorimetric Studies of the Interactions of Lysozyme with Immobilized $\mathrm{Cu}(\mathrm{II})$ : Effects of $\mathrm{pH}$ Value and Salt Concentration. J Colloid Interface Sci 190: 49-54.

23. Baydemir G, Andaç M, Derazshamshir A, Uygun DA, Özçaliskan, E, et al. (2013) Synthesis and characterization of amino acid containing $\mathrm{Cu}$ (II) chelated nanoparticles for lysozyme adsorption. Materials Science and Engineering: C 33: $532-536$

24. Graham B, Spiccia L, Hearn MT (2011) Comparison of the binding behavio of several histidine-containing proteins with immobilized copper(II) complexes of 1,4,7-triazacyclononane and 1,4-bis(1,4,7-triazacyclononan-1-yl)butane.J Chromatogr B Analyt Technol Biomed Life Sci 879: 844-852.

25. Góes LC, Miranda EA, Bueno SMA (2010) Interaction of histidine-tagged human proinsulin with immobilized nickel ion: Effect of chelating ligand and thermodynamics analysis. Colloids and Surfaces A: Physicochem. Eng. Aspects 369: 176-185
26. James EA, Do DD (1991) Equilibria of biomolecules on ion-exchange adsorbents. Journal Chromatography A 542: 19-28.

27. Jiang W, Hearn MT (1996) Protein interaction with immobilized metal ion affinity ligands under high ionic strength conditions. Anal Biochem 242: 45-54.

28. Sharma S, Agarwal GP (2001) Interactions of Proteins with Immobilized Metal Ions: Role of lonic Strength and $\mathrm{pH}$. Journal of Colloid and Interface Science 243: 61-72.

29. Sulkowski E (1985) Purification of proteins by IMAC. Trends in Biotechnology3: 1-7.

30. Mantovaara T, Pertoft H,Porath J (1991) Purification of factor VIII:c coagulant activity from rat liver nonparenchymal cell culture medium by immobilized metal ion affinity chromatography. Biotechnol Appl Biochem 13: 120-126.

31. Andersson L, Sulkowski E (1992) Evaluation of the interaction of protein alphaamino groups with $\mathrm{M}(\mathrm{II})$ by immobilized metal ion affinity chromatography. $J$ Chromatogr 604: 13-17.

32. Arnold FH (1991) Metal-affinity separations: a new dimension in protein processing. Biotechnology (N Y) 9: 151-156.

33. Patwardhan AV, Ataai MM (1997) Site accessibility and the $\mathrm{pH}$ dependence of the saturation capacity of a highly cross-linked matrix. Immobilized metal affinity chromatography of bovine serum albumin on chelating Superose. $J$ Chromatogr A 767: 11-23. 